Signs and Symptoms 

PETER L. COOPER

\section{Signs and Symptoms}

\section{Thomas Pynchon and the Contemporary World}

University of California Press

Berkeley | Los Angeles | London 
University of California Press

Berkeley and Los Angeles, California

University of California Press, Ltd.

London, England

C1983 by

The Regents of the University of California

Library of Congress Cataloging in Publication Data

Cooper, Peter L.

Signs and symptoms.

Bibliography: $p$.

1. Pynchon, Thomas-Criticism and interpretation.

I. Title.

PS3566.Y55Z58 $1982 \quad 813^{\prime} .54 \quad 82-6929$

ISBN 0-520-04537-8 AACR2

Printed in the United States of America

$\begin{array}{lllllllll}1 & 2 & 3 & 4 & 5 & 6 & 7 & 8 & 9\end{array}$ 
For Karen and Jessica 
